\title{
A New Monograph on Paleosols in River Valleys ${ }^{1}$
}

\author{
I. I. Sudnitsyn \\ Faculty of Soil Science, Moscow State University, Moscow, 119991 Russia \\ Received July 3, 2008
}

\begin{abstract}
DOI: $10.1134 / \mathrm{S} 1064229309070151$
\end{abstract}
Historical geology was shaped as a separate branch of geology dealing with the history of the development of the Earth's crust (and the Earth as a whole) in the first half of the 19th century. The appearance of this science is associated with the names of G. Cuvier, Ch. Lyell, W. Smith, and other outstanding scientists. Pedology as an independent scientific discipline appeared 50 years later, and historical pedology (paleopedology) is still being developed. In order to predict the soil behavior in the future, we have to know the soil responses to changes in the natural and anthropogenic factors of soil formation in the historical past. This is the main challenge of paleopedology. Valuable information on soils of the past can be obtained from paleosols buried under various dated historical monuments and from surface soils developed on dated surfaces of kurgans and habitation deposits. The monograph under review is devoted to such objects in the area of the Arkaim Natural-Historical Reserve in Chelyabinsk oblast.

The Arkaim site belongs to the Northern Kazakhstan soil province of ordinary and southern mediumdeep and shallow chernozems developing under herbaceous feather grass-fescue vegetation from the Neogene and Quaternary covering loamy deposits. Solods and gray forest soils are formed under forest groves in local mesodepressions; meadow soils, solonchaks, and solonetzes predominate in river valleys. A specific feature of this territory (in contrast to many other steppe areas) is the distribution of the soils by the elements of the microtopography: meadow-chernozemic soils occupy microhighs, and solonchaks and solonetzes are found in microdepressions with shallow groundwater (normally, the reverse pattern is observed).

A versatile study of ancient buried soils made it possible to suppose that chernozemic processes predominated on drained elements of the topography during the last four thousand years. Meadow-chernozemic soils of river valleys are somewhat heavier in texture than the soils of the interfluves and are developed from two-layered parent materials. These soils have undergone several stages of salinization, solonetzic, and solodic pro-

\footnotetext{
${ }^{1}$ Plekhanova, L.N., Demkin, V.A., and Zdanovich, G.B. Evolyutsiya pochv rechnykh dolin stepnogo Zaural'ya (Soil Evolution in River Valleys of Trans-Ural Steppes), Moscow, Nauka, 2007, 236 pp.
}

cesses. The features shaped by these processes are still preserved as relict features in the profiles of the modern surface soils. The authors concluded that the development of modern solonetzic and solonchakous chernozemic soils on river terraces was affected by natural and anthropogenic factors, including the heavy grazing pressure on the territory in the middle of the second millennium $\mathrm{BC}$ and the aridization of the climate in the first millennium BC. The natural climatic fluctuations and the anthropogenic destruction of vegetation (in particular, in the recent decades) have favored the general aridization of the territory and the development of saltaffected soils.

The upper part of the cultural layer of ancient settlements is considerably transformed by the pedogenetic processes. At present, meadow-chernozemic soils are developed from this specific parent material. These soils are easily subjected to wind erosion. In the areas of ancient settlements currently used for grazing, the thickness of the upper humus layer does not exceed 10$12 \mathrm{~cm}$; in the areas of ancient settlements that are not subjected to the anthropogenic loads, it increases to $30 \mathrm{~cm}$. At the same time, the thickness of the humus layer in the meadow-chernozemic soils developed from the natural covering deposits is about $60 \mathrm{~cm}$.

This monograph suggests a comprehensive analysis of the initial stages of urbanization (the appearance of permanent settlements) of steppe landscapes in the Late Bronze epoch. The kurgans studied by the authors belong to a huge cultural center currently known as the "country of towns" in the Trans-Ural steppe. The study of the soil evolution under the impact of heavy anthropogenic loads in the past (the retrospective analysis of the soil evolution) in such zones is of great value for the theory of pedology. It may also give us the key for solving acute ecological problems of nature management in the steppe zone.

In this context, I consider the monograph written by L.N. Plekhanova, V.A. Demkin, and G.B. Zdanovich to be both a valuable contribution to paleopedology and a guide to the practice of nature management in steppe regions. 